\title{
Prosa de ficção e apelos teatrais: Manuel da Fonseca, José Luandino Vieira, Mia Couto, Guimarães Rosa
}

\author{
Maria Aparecida Santilli \\ Universidade de São Paulo
}

RESUMO: DESDE QUE AS CONVENÇÕES CLÁSSICAS SOBRE OS CÂNONES DO DISCURSO COMEÇARAM A SER MAIS LARGAMENTE DESCUMPRIDAS, CONFUNDIRAM-SE TAMBÉM AS FRONTEIRAS DOS GÊNEROS LITERÁRIOS. NESSE SENTIDO, O PRESENTE TRABALHO ANALISA ALGUNS CONTOS DA PRODUÇÃO LITERÁRIA EM LÍNGUA PORTUGUESA OS QUAIS, PRÓDIGOS EM RECURSOS CÊNICOS OU EM OUTRAS LINGUAGENS VISUALIZÁVEIS, ENGENDRAM, COM SUAS HISTÓRIAS, EMBRIÕES DE ESPETÁCULOS, QUE DEMANDARIAM UM ESPAÇO COMO O PALCO OU A TELA PARA CONSUMAR SUA PLENITUDE POTENCIAL DE SENTIDO.

ABSTRACT: SINCE THE CLASSICAL CONVENTIONS ON THE CANONS OF DISCOURSE STARTED TO BE DISRESPECTED, THE FRONTIERS AMONG THE LITERARY GENRES ALSO BEGAN TO FALL DOWN. IN THIS SENSE, THIS ARTICLE ANALYZES CERTAIN SHORT STORIES PRODUCED WITHIN THE LITERARY SYSTEMS IN PORTUGUESE WHICH, SHOWING A PROFUSION OF SCENIC TRACES OR OTHER VISUAL RESOURCES, CREATE, WITHIN THEIR TEXTS, EMBRYOS OF SPECTACLES THAT CLAIM FOR A STAGE OR A SCREEN TO CONSUMMATE THEIR POTENTIAL PLENITUDE OF SENSE.

PALAVRAS-CHAVE: LITERATURA E ARTES CÊNICAS - LITERATURAS EM LIINGUA PORTUGUESA - MANUEL DA FONSECA - LUANDINO VIEIRA - MIA COUTO - GUIMARÃES ROSA KEY-WORDS: LITERATURE AND DRAMA - LITERATURES IN PORTUGUESE - MANUEL DA FONSECA - LUANDINO VIEIRA - MIA COUTO - GUIMARÃES ROSA 
alar de histórias espetaculares é, desde logo, criar expectativas com relação a uma modalidade especial de representação, a que se atribui ao teatro. Induz a imaginar palco - que, conforme adverte Käte Hamburger, é a função parcial não-literária - e atores, que, na condição de personagens dramáticos, absorvem as frases que os constituem e, por isso mesmo, são encarnados com os meios da realidade física, segundo também assinala Hamburger (1975: 143), indo além: “[...] a posição lógico-lingüística do drama no sistema da criação literária resulta unicamente da ausência da função narrativa, do fato estrutural de que os personagens são formados dialogicamente" [...]; “os personagens representados apenas pela sua fala, criam-se a si mesmos por ela" (HAMBURGER, 1975: 139).

Mas os autores apresentados no título deste trabalho não são aqui trazidos como dramaturgos, mas por sua prosa de ficção, mais particularmente enquanto celebrados contistas das literaturas de língua portuguesa. Por que, então, tratar de suas histórias justamente como espetaculares?

Antes de examinar os próprios contos escolhidos, por meio do que se presume justificar as razões de literariedade dessa opção, cabe lembrar que a confusão dos gêneros, tão abertamente advogada e praticada nos tempos românticos e de que é célebre exemplo o famoso Préface de Cromwell (1827), já vinha de antes. Erich Auerbach, em sua "Doutrina geral das épocas literárias" (1972), encontrava nos enciclopedistas o espírito libertário que minaria a resistência dos cânones dominantes desde a antiguidade greco-latina. Quando se reporta à Enciclopédia, que já não era sistemática como as antigas, porque "classificava os conhecimentos sem distinção de dignidade religiosa, moral ou estética" (AUERBACH, 1972: 220), vai também a Diderot, para quem imitar a natureza "[...] é imitar toda a verdade da vida, o feio e o belo; ele abandona assim a teoria clássica dos gêneros, que distinguia o trágico nobre e o cômico realista, e teria preparado a grande revolução estética que se produziu no século XIX se não tivesse tido, da realidade humana, uma concepção demasiadamente fácil e superficial"; Diderot, para Auerbach, "não fez mais que substituir uma convenção artística por outra menos nobre” (AUERBACH, 1972: 222).

De qualquer maneira, a rebeldia de Victor Hugo faria história. Em Introduction a Cromwell, Annie Ubersfeld vê que "Le mot clef de la Préface, c'est liberte", entre outras formas, "Liberté, la possibilité du mélange des genres" (1968: 47). 
Mikhail Bakhtin, por outro lado, em Questões de literatura e de estética, analisa o fenômeno literário que ele intitula de "romancização da literatura", dando sua resposta ao que seria "romancização dos outros gêneros".

Entre contistas, encontram-se casos notáveis de narradores, pela forma particular de aliciamento dos receptores de suas mensagens. Trata-se daqueles que apelam para o exercício do olhar.

Pródigos em recursos cênicos, ou outras linguagens visualizáveis na transfusão das palavras, engendram, com suas histórias, embriões de espetáculos que demandariam um espaço como o palco, ou a tela, onde se consumaria a concernente plenitude potencial.

Esta proposta - que se recorta na produção literária em língua portuguesa - será de focalizar alguns contos exemplares nesse aspecto: "Meio pão com recordações", de Manuel da Fonseca; "O fato completo de Lucas Matesso", de José Luandino Vieira; "O dia em que explodiu Mabata-Bata", de Mia Couto, e "A hora e a vez de Augusto Matraga", de Guimarães Rosa.

Desde que as convenções clássicas, de observância rigorosa de cânones do discurso, começaram a ser mais largamente descumpridas, ultrapassando os limites de tolerância relativos aos desvios de norma facultados à criatividade artística, confundiram-se, também, como se sabe, as fronteiras, antes bem guardadas, dos gêneros literários.

Quando se lembra o "Prefácio" de Cromwell, adivinha-se uma gama de práticas concessivas que, na prosa de ficção romântica portuguesa, pode ser bem ilustrada pelas Viagens na minha terra, de Almeida Garrett, em que a crônica de viagens, a lírica amorosa, o ensaísmo - como, no caso, motivado pela ideologia liberal da época - e a novela sentimental tipicamente romântica adequaram-se num todo de compatibilização textual a que, então, se abria caminho.

No desenrolar do último século do milênio foi possível observar como essa prática se assimilou e se fez tão recorrente, a ponto de já não causar, por si só, efeitos de estranhamento. Ou seja, a dita "mistura", ou a familiaridade com essa mistura, passou a fazer parte da gama de expectativas do leitor.

No decurso do processo, passou a interessar, também, à análise e à crítica literária o quê e o como dos arranjos intertextuais, a seduzir a arte de produzir textos, por estruturação com quaisquer várias modalidades tipológicas textuais. 
Está aí o romance de José Saramago para mostrar, por exemplo, como a escrita pragmática da História pode "melar-se" como matéria, da contextualidade poética em que vai se integrar.

Estas considerações preliminares em torno de mestiçagem de gêneros vinham ao caso para justificar a opção aqui posta, de falar de histórias espetaculares, de contaminação de prosa de ficção e teatro, todas de autoria de escritores de língua portuguesa, ainda que com registros de nacionalidade que se inscrevem na Europa, na América e na África.

A escolha foi suscitada justamente tomando como ponto de partida esse tipo de analogia, com que fazem contraponto as previsíveis diversidades. Recebidas e estimadas como prova de ficção - portanto, para serem lidas -, essas obras revelam, entretanto, ao leitor uma prodigalidade em recursos cênicos ou formas de comunicação em que, às palavras, subjaz um apelo à transcodificação semiótica, à tradução em linguagem visual.

A falta de pesquisa me inibe de generalizar a suposição de que o conto está mais próximo do teatro. Creio, entretanto, que, nestes contos que escolhi, possa dizer que o fato de tratar-se de contos favorece o parentesco com o teatro.

Os contos que agora passo a enumerar serão objeto de uma muito rápida abordagem, e tão-só para pôr em pauta uma proposta a mais de os entender e de acenar com outra possível pista de investigação, de gerar conhecimento. São eles: "Meio pão com recordação", de Manuel da Fonseca; "O fato completo de Lucas Matesso", de José Luandino Vieira; "O dia em que explodiu Mabata-Bata, de Mia Couto, e "A hora e a vez de Augusto Matraga", de João Guimarães Rosa.

Em todos eles tematiza-se a violência. Dir-se-ia, até, que sobressaem pelo tema, um tema de atualidade em sua (nossa?) geração. Está claro que esse tema se atualiza com a peculiaridade de cada particular contexto, nas correlações do indivíduo com o poder, em todos os casos singularizadas pelo momento e pelas condições étnicas em que se evidenciam.

Caberia notar que, assim, os contos do angolano José Luandino Vieira e do moçambicano Mia Couto ficam mais próximos entre si, estando ambos mais distantes daquele do contista português Manuel da Fonseca, enquanto no do brasileiro Guimarães rosa se acentuam as diferenças em relação a todos os demais.

Não comporta, nesta abordagem sumária, mergulhar em considerações de ordem conceitual ou histórico-literária que retardem o cumprimento de um 
objetivo estrito como é o de uma primeira rodada de constatações com o caráter específico já mencionado.

Posto isso, convém apenas lembrar que, no tocante a "O fato completo de Lucas Matesso" e a "O dia em que explodiu Mabata-Bata", a violência aparece institucionalizada, no sistema de guerras em que se funda o percurso diegético. Em "Meio pão com recordações", a violência avança introjetada no processo de gestação da luta de classes, ao passo que a de "A hora e a vez de Augusto Matraga" comanda-se pela ética esdrúxula da vendeta no sertão brasileiro concebido por Guimarães Rosa.

Centradas na violência estão as associações de motivos, em todos os casos. Essa violência constituirá uma razão para a escalada do trágico, na medida em que funciona para encaminhar a trama na direção irreversível do limite extremo a que os protagonistas se conduzem. Entendo que, por essa via, o epílogo é o momento privilegiado da narrativa, em todos esses contos que terminam no momento-chave de iluminação, de epifania, ao qual me reportarei.

Em "Meio pão com recordações", conto que é o embrião do romance Seara de vento, de Manuel da Fonseca, as duas mulheres - mãe e filha -, postas na situação de miséria de seu casebre, preparam, como se sabe, o que a mãe classificaria como "umas miseráveis sopas", enquanto dialogam. É na interlocução que se promove, progressivamente, o avanço do reconhecimento de si mesmas, na condição social em que vivem. As recordações servem menos ao seu comprazimento pelas lembranças de alguma fartura, ou seja, de um bem perdido, do que a marcar um estágio mais avançado e sem retorno no roteiro de uma definitiva queda em desgraça.

No desfecho desse conto de Manuel da Fonseca é particularmente enfática, pelos motivos aludidos, a utilização de recursos dramáticos que viriam a ser maximizados no romance Seara de Vento. São as mulheres, então, que protagonizam a conscientização da miséria, ou a violência em que implicam as carências sociais.

O progresso da ação por meio do diálogo, a gestualidade implícita nas descrições, as modulações de voz na indicação de variações de ânimo, as notações de ambiente que poderiam converter-se em expletivos visuais de palco conferem à narrativa um parentesco notável com o teatro.

Quanto ao conto "O dia em que explodiu Mabata-Bata", de Mia Couto, a história envereda por sucessos da faixa etária mais impotente, porque sub- 
metida às diversas instâncias de poder que lhe são sobrepostas. $\mathrm{O}$ menino a quem cabe personificar esses pesos da estrutura social ficará caracterizado por sua perspectiva dos fatos - o da explosão de Mabata-Bata e, por fim, a sua própria, que simbolizará o legado cultural de seu povo.

Nesse conto, os mesmos eventos percebem-se por duas óticas contrárias que correm paralelas até a cena final: aquela do menino-vítima, em cuja visão mítica as desgraças ligam-se à ave ndlati, e a dos adultos, que se constrói com os informantes "históricos" relativos às minas que detonam e vitimam, ou seja, os agentes dramáticos, responsáveis pelo final infeliz.

Também nesse conto os índices apelativos ao ver/ouvir são relevantes e incitam a imaginação por força sugestiva de estímulos sensoriais com outros procedimentos retóricos que tonalizam o texto como roteiro do palco e da tela.

Em Mia Couto, o estranho e o maravilhoso, pelos quais o conto se implanta nas velhas raízes da oralidade, não resultam de uma referência que seja bizarra, mas da percepção bizarra de determinada referência. Se magia nesse conto há, ela deriva da comoção que a função poética da linguagem a tal referência confere.

Ao considerar, por último, "A hora e a vez de Augusto Matraga", faço-o levando em conta a necessidade de contenção e de economia expositiva que rigidamente observei na abordagem dos demais, para reservar algum espaço à citação do texto de Guimarães Rosa e para um mínimo exame pontual por meio do qual melhor se entende o título desta comunicação: "Histórias espetaculares: Manuel da Fonseca, José Luandino Vieira, Mia Couto, Guimarães Rosa".

Que seja a citação do epílogo:

E o povo, enquanto isso, dizia: - Foi Deus quem mandou esse homem no jumento, por mor de salvar as famílias da gente!... E a turma começou a querer desfeitear o cadáver de seu Joãozinho Bem-Bem, todos cantando uma cantiga que qualquer um estava inventando na horinha:

Não me mata, não me mata

Seu Joãozinho Bem-Bem!

Você não presta mais pra nada, 
Seu Joãozinho Bem-Bem!...

Nhô Augusto falou, enérgico:

- Pára com essa matinata, cambada de gente herege!... E depois enterrem bem direitinho o corpo, com muito respeito e em chão sagrado, que esse aí é o meu parente Seu Joãozinho Bem-Bem!

E o velho choroso exclamava:

- Traz meus filhos, para agradecerem a ele, para beijarem os pés dele!... Não deixe este santo morrer assim... Pra que foi que foram inventar arma de fogo, meu Deus?!... Mas Nhô Augusto tinha o rosto radiante, e falou:

- Perguntem quem é aí que algum dia já ouviu falar nome de Nhô Augusto Esteves, das Pindaíbas!

- Virgem Santa! Eu logo vi que só podia ser você, meu primo Nhô Augusto... Era o João Lomba, conhecido velho e meio parente. Nhô Augusto riu.

- E hein, hein João?!

- Pra ver...

Então, Augusto Matraga fechou um pouco os olhos, com sorriso intenso nos lábios lambuzados de sangue, e de seu rosto subia um sério contentamento.

Daí, mais, olhou, procurando João Lomba, e disse, agora sussurrado, sumido:

- Põe a benção na minha filha... seja lá onde for que ela esteja... E, Dianóra... Fala com a Dianóra que está tudo em ordem!

Depois morreu. (ROSA, 1967)

Como se vê, essa instância final, também de coincidente clímax e reconhecimento, configura-se como cena, como completude de roteiro de uma peça teatral, na linha da tragédia. Note-se o diálogo, ou a seqüência de falas que o compõem por inteiro.

Nos dois protagonistas/antagonistas do conflito, Augusto Matraga e Seu Joãozinho Bem-Bem, corporifica-se toda a ação. Afora isso, algumas passa- 
gens de voz são articuladas pelo narrador, certamente por indispensável exigência de estabelecer o nexo temporal-causal.

Para já não mencionar a cantiga - que poderia vir a ser coral -, observe-se, além das indicações moduladoras da pontuação, o efeito conotativo derivado dos adjetivos que vale como substituto da linguagem gestual, na escrita: "falou, enérgico", "velho choroso"; "o rosto radiante"; "lábios lambuzados de sangue". Registre-se, ainda, a intensificação/progressão para uma ação "assistida": "fechou um pouco os olhos com sorriso intenso nos lábios", "de seu rosto subia um sério contentamento", "disse agora sussurrado". Com certeza, essas inserções narrativas estariam automaticamente suprimidas se o texto fundasse o espetáculo, porque absorvidas na representação corporal.

Se estas breves considerações comportam conclusão, que se diga que a incorporação de recursos dramáticos na prosa de ficção, pelo lado estético, resgata para os contadores de histórias o papel de minimizar a distância entre a sua palavra e o receptor dela, entre o mensageiro de um texto e aqueles a quem a mensagem quer alcançar.

Pelo lado da função social, os recursos da dramatização trazem a força multiplicada de fazer ver claro. Não é sem razão que o teatro sempre foi temido por esse seu potencial, sobretudo quando as relações entre o indivíduo e o poder a que está sujeito põem-se em questão.

Aí estão, nesses contos, os sinais anunciadores de que fazer ver claro, por vivificar uma experiência contada, é uma empresa que gera tais riscos. Glosando o próprio Guimarães, pode-se concluir: viver, mesmo efeitos dramáticos, é mesmo perigoso.

\section{Referências Bibliográficas}

AUERBACH, Erich. Introdução aos estudos literários. 2.ed. São Paulo: Cultrix, 1972. HAMBURGER, Käte. A lógica da criação literária. São Paulo: Perspectiva, 1975. ROSA, João Guimarães. Sagarana. 9. ed. Rio de Janeiro: José Olympio, 1967. 